REVISTA

\title{
DIVERSITY OF NITROGEN-FIXING BACTERIA IN COFFEE CROPS (Coffea arabica L.)
}

\author{
${ }^{1 *}$ Marliane de Cássia Soares da Silva. \\ ${ }^{2}$ Tomás Gomes Reis Veloso. \\ ${ }^{3}$ Thaynara Lorenzoni Entringer. \\ ${ }^{4}$ Vilian Borchardt Bullergahn. \\ ${ }^{5}$ Larissa Márcia Anastácio. \\ ${ }^{6}$ Lucas Louzada Pereira \\ ${ }^{7}$ Maria Catarina Megumi Kasuya
}

\begin{abstract}
${ }^{1}$ Universidade Federal de Viçosa. E-mail: marliane.silva@ufv.br. ${ }^{2}$ Universidade Federal de Viçosa. E-mail: tomasgomesrv@gmail.com. 33niversidade Federal de Viçosa. E-mail: thaynara.entringer@ufv.br. ${ }^{4}$ Universidade Federal de Viçosa. E-mail: vilian.bullergahn@ufv.br.

${ }^{5}$ Universidade Federal de Viçosa. E-mail: larissa.anastacio@ufv.br. ${ }^{6}$ Instituto Federal do Espírito Santo. E-mail: lucas.pereira@ifes.edu.br. ${ }^{7}$ Universidade Federal de Viçosa. E-mail: mkasuya@ufv.br *Autor de correspondência
\end{abstract}

Artigo submetido em 28/09/2020, aceito em 09/11/2020 e publicado em 23/12/2020.

Resumo: Os microrganismos são considerados importantes fatores biológicos para o crescimento e desenvolvimento das plantas e as bactérias fixadoras de nitrogênio (BFN) auxiliam diretamente a sua nutrição nitrogenada. Entretanto, poucos estudos têm avaliado esta importante comunidade bacteriana na cultura do café. Assim, o objetivo do presente estudo foi avaliar a diversidade de BFN nos solos e nos frutos de cafeeiros em oito propriedades. Após a extração de DNA, a subregião hipervariável V4, do rDNA da região $16 \mathrm{~S}$ foi amplificada e sequenciada na plataforma Ilumina Miseq. A predição funcional de batérias com potencial de fixação de nitrogênio molecular foi realizada com o programa PICRUSt2. Cento e dezoito Amplicons de Sequencias Únicas (ASVs) foram preditas como potenciais fixadoras de nitrogênio. Destas, apenas quatro foram detectadas em frutos. O filo mais abundante foi Proteobacteria (71 \%) seguido de Firmicutes (23 \%). A abundância relativa das BFN em relação ao total de bactérias do solo variou entre os três e cinco por cento. Nos grãos, essa abundância variou desde menos de um por cento a quase seis por cento. Apenas uma ASV da família Rhizobiaceae foi encontrada simultaneamente nos frutos e no solo. O gênero Bradyrhizobium foi detectado em todas as amostras de solo. Concluimos que importantes BFN fazem parte da microbiota presente no solo e fruto de café e que existe um compartilhamento entre eles. As evidências mostram que o gênero Bradyrhizobium pode ser considerado um importante componente da microbiota core do solo do cafeeiro.

Palavras chave: Rhizobiaceae, Proteobacteria, SNG, Amplicon Sequence Variants, café, frutos, solo, microbioma, bacteria diazotrófica. 
Abstract: Microorganisms play a crucial role in plant growth and development. NitrogenFixing Bacteria (NFB), for instance, are essential to plant nitrogen nutrition. However, few studies have been evaluated this important bacterial community in coffee agrosystems. Therefore, this study aims to evaluate the diversity of NFB in soil and fruits sampled from eight coffee farms. After DNA extraction, the V4 hypervariable region of $16 \mathrm{~S}$ rDNA was amplified and sequenced in Illumina MiSeq sequencer. The prediction of potential nitrogenfixing bacteria was performed by PICRUSt2. One hundred and eighteen ASVs were predicted as potential nitrogen-fixing. Among them, only four were found in fruits. The most abundant phylum was Proteobacteria (71 \%), followed by Firmicutes (23 \%). The relative abundance of the NFB concerning the whole bacterial community ranged from three to almost six percent. Only one ASV of the Rhizobiaceae family was found simultaneously in fruits and soil. The Bradyrhizobium genus was found in all soil samples. We conclude that important NFB are part of the microbiota present in the soil and coffee fruit and that there is a sharing ASV between them. There also is evidences that Bradyrhizobium genus can be considered a crucial component of the core microbiota in coffee soil.

Keywords: Rhizobiaceae, Proteobacteria, NGS, Amplicon sequence variants, coffee, fruits, soil, microbiome, diazotrophic bactéria.

\section{INTRODUCTION}

Coffee is a widely consumed beverage around the world being produced in several countries and under different conditions, which leads to a wide variation in the sensory profiles of coffee drinks (HORTA DE OLIVEIRA et al., 2018). These sensorial characteristics are exceptionally complex and influenced by many factors: the variety of coffee, management, altitude, and chemical, physical, and biological properties of the soil (NASANIT, SATAYAWUT, 2015; VELOSO et al., 2020).

Among the biological properties, the beneficial microorganisms that colonize the plant compartments (epiphytic, endophytic, and rhizospheric) promotes plant growth through direct and indirect mechanisms, such as biological nitrogen fixation (BNF), production of plant growth hormones, siderophores, hydrolytic enzymes and solubilization of potassium (K), zinc (Zn), and phosphorus (P), and act directly on the biogeochemical cycles of $\mathrm{C}$ (carbon), $\mathrm{N}$ (nitrogen), and P (TRISTÃO et al., 2006; FONSECA et al., 2018 and KOUR et al., 2020). Microorganisms can also favor the absorption of nutrients, protect against pathogens (FONSECA et al., 2019;
FORMENTI and RASMANN, 2019), and drive the fermentation processes (DE MELO PEREIRA et al., 2020).

Coffee plants require large amounts of nutrients, especially $\mathrm{N}$. In the majority of tropical soils, the deficiency of this nutrient leads the crops being very dependent on the application of synthetic nitrogen fertilizers or alternative sources of nitrogen (PAULINO et al., 2009). In suitable environmental conditions, the atmospheric nitrogen is fixed by nitrogen-fixing bacteria (NFB), providing part of the nitrogen required by the plant (MARTÍNEZROMERO, 2009). NFB are also known as diazotrophic bacteria. Although no nodule formation occurs in the roots, free-living, endophytic, and associative NFB can supply nitrogen nutrition (BALDANI; BALDANI, 2005). Non-symbiotic NFB are genetically diverse, enabling them to colonize a wide variety of habitats (KENNEDY; CHOUDHURY; KECSKÉS, 2004).

In organic coffee systems, the use of legumes, such as Inga oerstediana, for shade, isolation, and characterization of bacteria forming root nodules has been carried out as well as the evaluation of their effectiveness in fixing atmospheric nitrogen (GROSSMAN et al., 2005 and 
GROSSMAN et al., 2006). In these agroecosystems, the diversity of nodulating bacteria of leguminous are greater than those found in coffee agroecosystems shaded by non-woody trees, such as Michelia champaca, and coffee agroecosystems without shade trees (EVIZAL et al., 2013). The NFB contribute with about $80 \%$ of the $\mathrm{N}$ accumulated by legumes, and part of the $\mathrm{N}$ needed for coffee can be supplied by these plants (MENDONÇA et al., 2017; PARTELLI et al., 2011) .

Furthermore, NFB have been isolated from tissues of the aerial part, rhizosphere, and rhizoplane of coffee plants (Coffea arábica L.) (FUENTES-RAMÍREZ et al., 2001). Nitrogen-fixing acetobacters associated with coffee can be agronomically important because they can supply part of the nitrogen required by the crop, as observed in the association of sugarcane with its endophytic NFB (JIMENEZSALGADO et al., 1997). Similarly, inoculation with Azospirillum brasilense is an alternative for increasing the productivity of corn crops in marginal areas, which enables to reduce the application of $\mathrm{N}$ chemical fertilizers (COELHO et al., 2020).

As there is few studies related to the diversity of this important group of bacteria in coffee, this study aimed to evaluate the diversity of NFB in the soil and fruits of coffee trees in eight coffee-producing farms.

\section{MATERIAL AND METHODS}

This research was carried out in two laboratories: Laboratório de Associações Micorrízicas and Laboratório de Genética de Microrganismos, both belonging to Departamento de Microbiologia, located at Instituto de Biotecnologia Aplicada à Agropecuária (Bioagro), in the Universidade Federal de Viçosa (UFV), Viçosa, Minas Gerais, Brazil.

\subsection{SAMPLING}

Twenty-four composite samples of soil and fruits of Red Catuaí 81 (Coffea arabica $L$.) were collected from eight small agricultural farms in the southwest region of the state of Espírito Santo (Figure 1). Each composite sample of fruits was obtained from 30 coffee fruits from three plants. The composite samples of soil, in turn, were build by mixing three sub-samples of $0-10$ $\mathrm{cm}$ depth and from at $40 \mathrm{~cm}$ of radius from the plant's stem (VELOSO et al., 2020). All samples were kept in plastic bags and stored on ice. After transport to the laboratory, they were kept at $-20{ }^{\circ} \mathrm{C}$ for up to two months before processing.

\subsection{DNA EXTRACTION, PCR AND SEQUENCING}

Approximately $250 \mathrm{mg}$ of soil or fruits were macerated in liquid nitrogen to extract the metagenomic DNA, using the

Figure 1. Location map of the eight small agricultural farms. The properties are all located in three municipalities: Afonso Claudio, Venda Nova do Imigrante and Castelo, in the State of Espírito Santo, Brazil

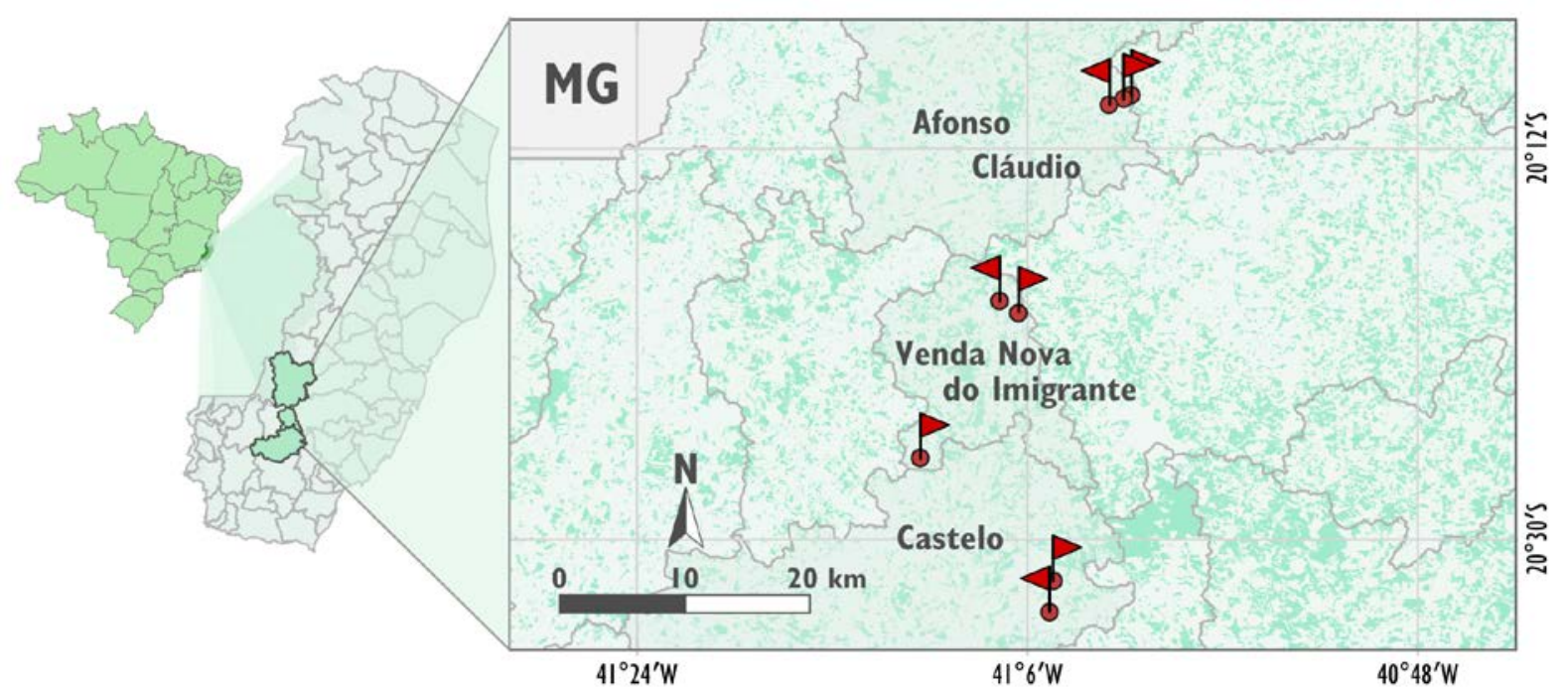


Nucleo Spin Soil (Macherey-Nagel, GmbH \& Co. KG, Germany). The cell lysis was performed inside microtubes containing ceramic beads at $4000 \mathrm{rpm}$ for $48 \mathrm{~s}$ in Precellys 24 homogenizer (Bertin Technologies). The downstream steps of DNA extraction were performed according to the manufacture's recommendations (Macherey-Nagel, GmbH \& Co. KG, Germany). The quality of the extracted DNA was analyzed by electrophoresis using a $0.8 \%$ agarose gel stained with ethidium bromide under UV light and a digital camera.

The libraries of the V4 hypervariable subregion from the 16S rDNA were built by amplifying it with the pair of primers $515 \mathrm{~F}$ (5' GTGYCAGCMGCCGCGGTAA 3') and 806R (5' GGACTACNVGGGTWTCTAAT 3'). All the libraries were normalized at equal, $2 \mathrm{nM}$ per library, before pooling the samples. The sequencing was performed using the platform Illumina Miseq in the form of paired-end reads with $151 \mathrm{bp}$. The raw reads were deposited in the public database NCBI-SRA and can be accessed using the BioProject PRJNA626678.

\subsection{PROCESSING OF 16S AMPLICONS}

The sequences were demultiplexed and trimmed to remove primers, barcodes, and adapters. All reads with a maximum expected error of one or more were removed to keep only high-quality sequences. Then, we removed all chimeras and singletons. The remaining sequences were clustered in Amplicon Sequence Variants (ASVs) (CALLAHAN et al., 2016). Each ASV was annotated using a pre-trained algorithm (classify-sklearn) with the SILVA 138 database. All sequences annotated as organelles (mitochondria, chloroplasts) were removed from the upstream analyses. All analyses were performed using Qiime2 version 2020.8 (BOLYEN et al., 2019).
The functional prediction of potential nitrogen-fixing bacteria was done by a Phylogenetic Investigation of Communities by Reconstruction of Unobserved States (PICRUSt2) (DOUGLAS et al., 2020). Each ASV was placed in a phylogenetic tree based on the 16S marker gene where the genome of all bacteria in the tree are known. All sequences with the Nearest Sequence Taxon Index (NSTI) above one were removed to ensure a high accuracy prediction. From the predicted metagenome, all selected ASVs had in their genome, genes related to nitrogen fixation, based on MetaCyc database (EC:1.18.6.1 e EC:1.19.6.1).

\section{RESULTS AND DISCUSSION}

One hundred eighteen ASVs were predicted as NFB potencies (Figure 2). Only four were detected in fruits (3.4\%) and 115 in the soil (97.5 \%). Two nitrogen fixation pathways are present in the MetaCyc database: one that uses ferredoxin as an electron donor (EC:1.18.6.1) and another that uses flavodoxin (EC:1.19.6.1).

Only genes related to the pathway using ferredoxin (EC: 1.18.6.1) were detected. The use of Flavodoxin may be related to environments with little iron available (MAYHEW; TOLLIN, 2019). However, there is high availability of iron in the analyzed soils. NFB have already been reported in coffee plant tissues and soil (JIMENEZ-SALGADO et al., 1997). The frequency of isolation of these bacteria present in the soil varies from 15 to $40 \%$ and is dependent on the $\mathrm{pH}$ of these places (JIMENEZ-SALGADO et al., 1997). Endophytic NFB may be more prevalent than previously thought, and perhaps there are many other potentially beneficial NFB that can be isolated from other important agronomic crops (JIMENEZ-SALGADO et al., 1997). 
The most abundant phylum, Proteobacteria, corresponded to more than two-thirds of ASVs (84 ASVs; $71.2 \%$ ), followed by Firmicutes represented by 27 ASVs (22.9 \%) (Figure 2). The phylum proteobacteria was also more abundant in coffee plantations in intensive, organic systems, and transition from intensive to organic with 32.7, 32.8 and $29.7 \%$ respectively (CALDWELL et al., 2015). The Proteobacteria phylum was also found to be more abundant in the wheat rhizosphere with 36 to $41.7 \%$ (KAVAMURA et al., 2020; ROSSMANN

Figure 2: Amplicon Sequence Variants (ASVs) predicted as Nitrogen Fixing Bacteria by picrust2. The outermost ring indicates the presece (blue) or absence (gray) of the ASV in soil, while the innermost ring indicates the presence (red) or abscence (gray) in fruits. Un = Unidentified; Unc = Uncultured; IS = Insertae sedis; Dip = Diplorickettsiales; San =

Sandaracinaceae; Bur = Burkholderiaceae; Rhod $=$ Rhodobacterales; Rho $=$ Rhodobacteraceae; Micr = Micropepsales; Mic = Micropepsaceae; Hal = Haliangiaceae; Nos = Nostocales; Oxy = Oxyphotobacteria; Sub25 = Subgroup 25; Arma = Armatimonadales;

Arm = Armatimonadia; ArmatimonadalesChth = Chthonomonadetes; Cht $=$ Chthonomonadales; Sel = Selenomonadales; Vei = Veillonellaceae; Pae = Paenibacillaceae;

Bac = Bacillales; Pep = Peptostreptococcaceae; Hel = Heliobacteriaceae; $\mathrm{Clo}=$ Clostridiaceae 2; Pepc = Peptococcaceae; Rum = Ruminococcaceae .

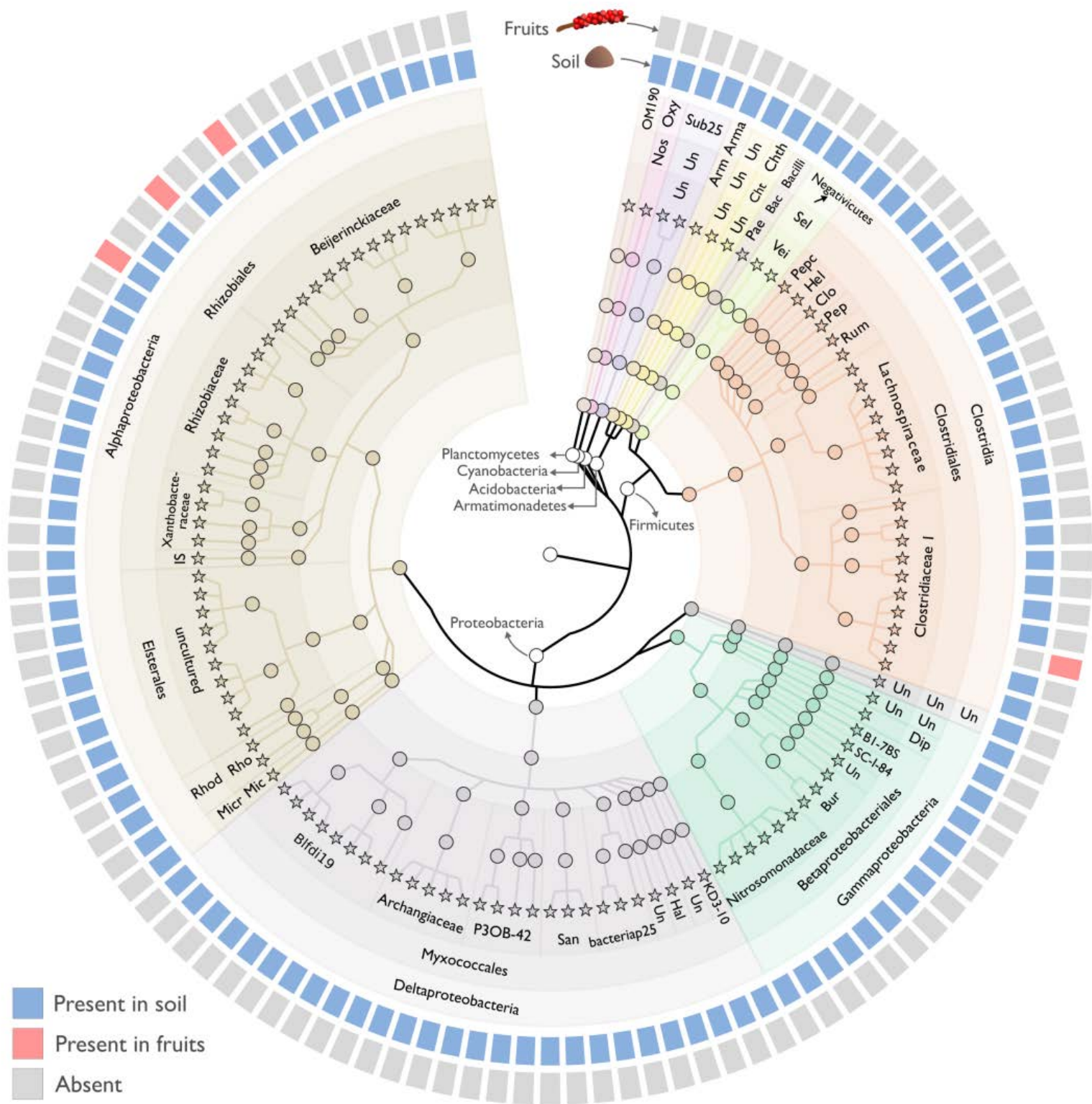


et al., 2020). As well as in endophytic plant communities, where members of Proteobacteria and Firmicutes are found in greater proportion (TRIVEDI et al., 2020). Using the sequencing of the nif $\mathrm{H}$ gene, the predominance of the phylum Proteobacteria was also observed in desert soils (MIAO et al., 2020).

The phylum Proteobacteria has important genera of diazotrophs, such as Azospirillum, Bradyrhizobium, and Mesorhizobium, which have been identified as the taxa of great importance and can form mutualistic relationships with other soil microbial populations (MIAO et al., 2020). The genus Azospirillum was not found in this work, but it is a very commom genus that performs the nitrogen fixation, and has been found in the soil, as well as part of the plant tissue. It can also produce plant growth promoters, such as indol acetic acid (IAA), gibberellins, and cytokinins (KOUR et al., 2020). The Firmicutes phylum has also important genera such as Paenibacillus known as insoluble $\mathrm{P}$ and $\mathrm{K}$ solubilizers and also as a potential for biological control (ZHANG et al., 2013). Bacteria of this genus have the genes that code for ferredoxin reductase and ferredoxin nitrite reductase, synthesis of IAA, and siderophores as growth promotion strategies (ZHOU et al., 2020).

In lesser proportions were found phyla Armatimonadetes (4 ASVs; $3.4 \%$ ), Acidobacteria (2 ASVs; $1.7 \%$ ), Cyanobacteria (1 ASV; $0.85 \%$ and Planctomyces (1 ASV; 0.85 \%) (Figure 2). The last three phyla were also found in smaller proportions in rhizospheric soil, phyllosphere, and as root and leaf endophytes (TRIVEDI et al., 2020). The phylum Armatimonadetes described by Tamaki et al. (2011) has three main characteristics, relatively high abundance, is present in several habitats, and difficult to obtain in pure culture (HU et al., 2014).

Several factors can modify the microbial communities that interact with the plants, such as changes in the cultivars can affect the plants' ability to recruit and sustain a complex network of bacterial communities in the rhizosphere (KAVAMURA et al., 2020). As well as the environment where different communities are present, such as in agricultural soils with a greater abundance of Acidobacteria, Bacteroidetes, Chloroflexi, Nitrospirae, and Gemmatimonadetes, while Actinobacteria, Verrucomicrobia, and Firmicutes were more abundant in the rhizosphere of plants cultivated in forest soil (ROSSMANN et al., 2020). Among soil properties, the available phosphate is one of the main factors in determining the composition of the diazotrophic community (ZOU et al., 2020), as well as the climatic factors and spatial distance, that together influenced this community (HAN et al., 2019).

Only one ASV of the Rhizobiaceae family was found simultaneously in the fruits and the soil (Figure 2). This family comprises a great diversity of NFB, the most well-known genera, Allorhizobium, Azorhizobium, Bradyrhizobium, Mesorhizobium, Sinorhizobium, and Rhizobium, which is an important genera of symbiotic bacteria that lives in root nodules forming a mutualistic relationship with legumes (KOUR et al., 2020).

The relative abundance of NFB concerning the total of soil bacteria varied between three and five percent (Figure 3). In fruits , on the other hand, this abundance varied from less than one percent to almost six percent, yet, in the vast majority of analyzed samples no NFB was detected (Figure 3). This abundance is quite variable for NFB between different agrosystems (HE et al., 2020), and it can also vary depending on the culture, management, and availability of nutrients (ZOU et al., 2020). There was greater abundance in soybean than in corn, and it also increased notably in the crop rotation system in relation to the continuous system (ZOU et al., 2020). The consortium system has also had a positive effect on the growth of diazotrophic communities and can boost soil fertility (SOLANKI et al., 
Figure 3: (A) Relative abundance of predicted nitrogen-fixing bacteria regarding to the total bacteria in the samples. (B) Most frequent bacterial genera in soil and fruits of coffee. Taxons marked with an asterisk (*) indicate unidentified genera using the SILVA 138 database. In these cases, they were annotated with the nearest taxonomic level available.

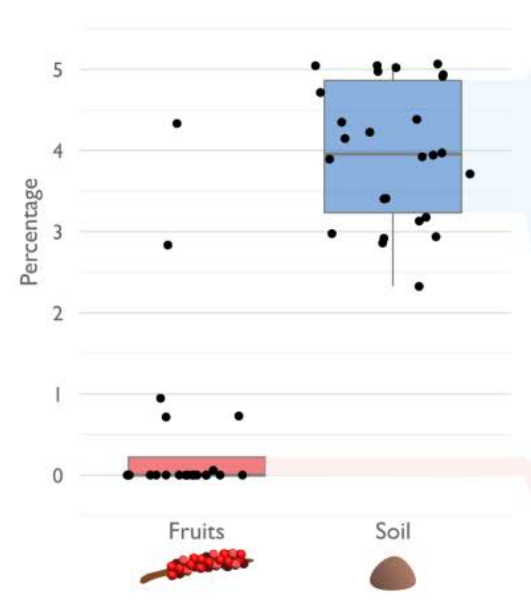

2018). Nutrients such as total nitrogen and soil $\mathrm{pH}$ affect the abundance and activity of diazotrophs, respectively (HAN et al., 2019).

The most abundant genera were found at all altitudes except for Clostridium genus stricto sensu 12, an unidentified genus of the order Myxococcales (Bifidi 19), one of the order Betaproteobacteriales, one of the phylum Acidobacteria (subgroup 25), and two of the order Betaproteobacteriales (Figure 3 b). This result indicates that the NFB potential is well distributed in soils where the coffee tree is grown.

The genus Bradyrhizobium was detected in all soil samples, revealing to be a genus that participates of the core microbiota in the soil of coffee crops (Figure 3). This genus was also considered the core microbione among the diazotrophs of different Chinese soil and responsible for the interaction with other diazotrophs (HAN et al., 2019). It has been the species used as inoculants in legumes (PEREIRA et al., 2010; ULZEN et al., 2016), such as soybean where in the nodules Bradyrhizobium is able fixes a large part of the $\mathrm{N}$ used by the plant (ARAUJO et al., 2019).

A minority of NFB species are involved in symbiosis, and free-living diazotrophic species have received little attention and are still poorly characterized (SHIN et al., 2016). This work shows the presence of these bacteria in coffee plantations located in different properties and altitudes and reinforces their importance for this crop. The study of this community can lead to the development of technologies such as microbial inoculants that help in the incorporation of nitrogen into the cultivated soil, with consequent reducing the need for nitrogen fertilizer addition.

\section{CONCLUSIONS}

Important NFB are part of the microbiota present in the soil and coffee fruit.

The potential for nitrogen fixation is distributed along six bacterial phyla, showing that the soils of the coffee trees display a high genetic diversity of this group of microorganisms. 
There is a sharing of NFB between fruit and soil, but only from members of the Rhizobiaceae family.

The Bradyrhizobium genus can be considered an important component of the core microbiota in soil of coffee crops.

\section{ACKNOWLEDGMENTS}

The authors acknowledge the financial support and fellowships provided for the project to Conselho Nacional de Desenvolvimento Científico e TecnológicoCNPq (process number 469058/2014-5), Secretaria de Educação Profissional e Tecnológica - SETEC, CAPES (Coordenação de Aperfeiçoamento de Pessoal de Nível Superior - Código de Financiamento 001), and Fundação de Amparo à Pesquisa do Estado de Minas Gerais (FAPEMIG). The authors would like to thank the Federal Institute of Espírito Santo, for supporting the research, through the PRPPG Edital No. 10/2019 Productivity Researcher Program - PPP.

\section{REFERENCES}

ARAUJO, Karla Emanuelle Campos et al. Natural abundance of $15 \mathrm{~N}$ of $\mathrm{N}$ derived from the atmosphere by different strains of Bradyrhizobium in symbiosis with soybean plants. Ciencia Rural, [s. l.], v. 49, n. 12, 2019.

BALDANI, José I.; BALDANI, Vera L. D. History on the biological nitrogen fixation research in graminaceous plants: Special emphasis on the Brazilian experience. Anais da Academia Brasileira de Ciencias, [s. l.], v. 77, n. 3, p. 549-579, 2005.

BOLYEN, Evan et al. Reproducible, interactive, scalable and extensible microbiome data science using QIIME 2. Nature Biotechnology, [s. l.], v. 37, n. 8, p. 852-857, 2019.
CALDWELL, Adam Collins et al. Prokaryotic diversity in the rhizosphere of organic, intensive, and transitional coffee farms in Brazil. PLoS ONE, [s. l.], v. 10, n. 6, 2015.

CALLAHAN, Benjamin J. et al. DADA2: High-resolution sample inference from Illumina amplicon data. Nature Methods, [s. l.], v. 13, n. 7, p. 581-583, 2016. Disponível em: $<$ https://doi.org/10.1038/nmeth.3869>

COELHO, Steliane Pereira et al. Azospirillum brasilense increases corn growth and yield in conventional low input cropping systems. Renewable Agriculture and Food Systems, [s. l.], p. 1-9, 2020.

DE MELO PEREIRA, Gilberto V. et al. Lactic acid bacteria: what coffee industry should know? Current Opinion in Food Science, [s. l.], v. 31, p. 1-8, 2020.

DOUGLAS, Gavin M. et al. PICRUSt2 for prediction of metagenome functions. Nature Biotechnology, [s. 1.], v. 38, n. 6, p. 685-688, 2020. Disponível em: $<$ https://doi.org/10.1038/s41587-020-05486>

EVIZAL, R. et al. Diversity of legume nodulating bacteria as key variable of coffee agro-ecosystem productivity. International research journal of agricultural science and soil science, [s. 1.], v. 3, n. 4, p. 141146, 2013.

FONSECA, Arley José et al. Arbuscular mycorrhizal fungus on the initial growth and nutrition of Coffea arabica L. Genotypes. Ciencia e Agrotecnologia, [s. l.], v. 43, p. 1-11, 2019.

FORMENTI, Ludovico; RASMANN, Sergio. Mycorrhizal fungi enhance resistance to herbivores in tomato plants with reduced jasmonic acid production. Agronomy, [s. l.], v. 9, n. 3, 2019. 
FUENTES-RAMÍREZ, L. E. et al. Novel nitrogen-fixing acetic acid bacteria, Gluconacetobacter johannae sp. nov. and Gluconacetobacter azotocaptans sp. nov., associated with coffee plants. International Journal of Systematic and Evolutionary Microbiology, [s. l.], v. 51, n. 4, p. 13051314, 2001.

GROSSMAN, J. M. et al. Characterization of slow-growing root nodule bacteria from Inga oerstediana in organic coffee agroecosystems in Chiapas, Mexico. Applied Soil Ecology, [s. 1.], v. 29, n. 3, p. 236-251, 2005.

GROSSMAN, J. M. et al. An assessment of nodulation and nitrogen fixation in inoculated Inga oerstediana, a nitrogenfixing tree shading organically grown coffee in Chiapas, Mexico. Soil Biology and Biochemistry, [s. 1.], v. 38, n. 4, p. 769784, 2006.

HAN, Li Li et al. Multiple factors drive the abundance and diversity of the diazotrophic community in typical farmland soils of China. FEMS Microbiology Ecology, [s. l.], v. 95, n. 8, p. 1-10, 2019.

HE, Huan et al. The structure and diversity of nitrogen functional groups from different cropping systems in yellow river delta. Microorganisms, [s. l.], v. 8, n. 3, 2020.

HORTA DE OLIVEIRA, Gabriel Henrique H. et al. Coffee Quality: Cultivars, Blends, Processing, and Storage Impact. Journal of Food Quality, [s. 1.], v. 2018, 2018.

$\mathrm{HU}, \mathrm{Zi}$ Ye et al. The first complete genome sequence of the class Fimbriimonadia in the phylum Armatimonadetes. PLoS ONE, [s. l.], v. 9, n. 6, 2014.

JIMENEZ-SALGADO, Teresita et al. Coffea arabica L., a new host plant for Acetobacter diazotrophicus, and isolation of other nitrogen-fixing acetobacteria. Applied and Environmental Microbiology, [s. 1.], v. 63, n. 9, p. 3676-3683, 1997.

KAVAMURA, Vanessa $\mathrm{N}$. et al. Wheat dwarfing influences selection of the rhizosphere microbiome. Scientific Reports, [s. l.], v. 10, n. 1, p. 1-11, 2020.

KENNEDY, Ivan R.; CHOUDHURY, A. T. M. A.; KECSKÉS, Mihály L. Nonsymbiotic bacterial diazotrophs in cropfarming systems: Can their potential for plant growth promotion be better exploited? Soil Biology and Biochemistry, [s. l.], v. 36, n. 8, p. 1229-1244, 2004.

KOUR, Divjot et al. Microbial biofertilizers: Bioresources and eco-friendly technologies for agricultural and environmental sustainability. Biocatalysis and Agricultural Biotechnology, [s. l.], v. 23, n. December 2019, p. 101487, 2020. Disponível em: $<$ https://doi.org/10.1016/j.bcab.2019.10148 7>

MARTÍNEZ-ROMERO, Esperanza. Coevolution in Rhizobium -Legume Symbiosis? DNA and Cell Biology, [s. l.], v. 28, n. 8, p. 361-370, 2009. Disponível em:

$<$ http://www.liebertpub.com/doi/10.1089/dn a.2009.0863>

MAYHEW, S. G.; TOLLIN, G. General properties of flavodoxins. In: Chemistry and Biochemistry of Flavoenzymes. Boca Raton - FL: CRC Press, 2019. p. 389-426.

MENDONÇA, Eduardo de Sá et al. Biological nitrogen fixation by legumes and $\mathrm{N}$ uptake by coffee plants. Revista Brasileira de Ciencia do Solo, [s. l.], v. 41, p. 1-10, 2017.

MIAO, Lin et al. Chemoheterotrophic diazotrophs contribute to nitrogen incorporation in a semi-arid desert. Biology and Fertility of Soils, [s. l.], 2020. 
NASANIT, Rujikan; SATAYAWUT, Komate. Microbiological study during coffee fermentation of Coffea arabica var. chiangmai 80 in Thailand. Kasetsart Journal - Natural Science, [s. 1.], v. 49, n. 1, p. 32-41, 2015.

PARTELLI, Fábio Luiz et al. Biologic dinitrogen fixation and nutrient cycling in cover crops and their effect on organic Conilon coffee. Semina:Ciencias Agrarias, [s. l.], v. 32, n. 3, p. 995-1006, 2011.

PAULINO, Gleicia Miranda et al. Fixação biológica e transferência de nitrogênio por leguminosas em pomar orgânico de mangueira e gravioleira. Pesquisa Agropecuária Brasileira, [s. l.], v. 44, n. 12, p. 1598-1607, 2009.

PEREIRA, Carlos Eduardo et al. Compatibility among fungicide treatments on soybean seeds through film coating and inoculation with Bradyrhizobium strains. Acta Scientiarum. Agronomy, [s. 1.], v. 32, p. 585-589, 2010. Disponível em: $<$ http://www.scielo.br/scielo.php?script=sci _arttext\&pid=S1807-

$86212010000400003 \& n r m=$ iso $>$

ROSSMANN, Maike et al. Multitrophic interactions in the rhizosphere microbiome of wheat: From bacteria and fungi to protists. FEMS Microbiology Ecology, [s. l.], v. 96, n. 4, 2020.

SHIN, Wansik et al. Role of Diazotrophic Bacteria in Biological Nitrogen Fixation and Plant Growth Improvement. Korean Journal of Soil Science and Fertilizer, [s. l.], v. 49, n. 1, p. 17-29, 2016.

SOLANKI, Manoj Kumar et al. Linkages of Soil Nutrients and Diazotrophic Microbiome under Sugarcane-Legume Intercropping. [s. l.], n. October, 2018.

TRISTÃO, Fabrício Sales Massafera; ANDRADE, Sara Adrian Lopez De; SILVEIRA, Adriana Parada Dias Da. Fungos micorrízicos arbusculares na formação de mudas de cafeeiro, em substratos orgânicos comerciais. Bragantia, [s. l.], v. 65, n. 4, p. 649-658, 2006.

TRIVEDI, Pankaj et al. Plant-microbiome interactions: from community assembly to plant health. Nature Reviews Microbiology, [s. l.], 2020. Disponível em: $<$ http://dx.doi.org/10.1038/s41579-0200412-1>

ULZEN, Jacob et al. Bradyrhizobium Inoculants Enhance Grain Yields of Soybean and Cowpea in Northern Ghana. Frontiers in Plant Science, [s. 1.], v. 7, p. 1770, 2016. Disponível em: <https://www.frontiersin.org/article/10.3389 /fpls.2016.01770>

YADESSA, A. et al. Influence of soil properties on cup quality of wild arabica coffee in coffee forest ecosystem of SW Ethiopia. 22nd International Conference on Coffee Science (ASIC), [s. 1.], n. June 2014, 2008.

ZHOU, Liangliang et al. Pan-genome analysis of Paenibacillus polymyxa strains reveals the mechanism of plant growth promotion and biocontrol. Antonie van Leeuwenhoek, International Journal of General and Molecular Microbiology, [s. l.], v. 0123456789, 2020. Disponível em: $<$ https://doi.org/10.1007/s10482-02001461-y>

ZOU, Jiaxun et al. Changes of diazotrophic communities in response to cropping systems in a Mollisol of Northeast China. PeerJ, [s. l.], v. 8, p. e9550, 2020. 